\title{
THE FRAMING OF THE FIRST HUNGARIAN CITIZENSHIP LAW (ACT 50 OF 1879) AND THE ACQUISITION OF CITIZENSHIP
}

\author{
NORBERT VARGA \\ University of Debrecen, Faculty of Political and Law Sciences, Debrecen \\ Hungary
}

\begin{abstract}
In 1879, Hungarian legislators deemed it was time to settle the issue of citizenship once and for all. The moment was not chosen by mere accident, because the previous years had witnessed an upsurge of legislative acts striving to legally settle the question of who should belong to the states of Europe. The bill was discussed and opined by the Naturalization Committee of the Parliament. The most important problems were the naturalization and the absence. The first regulation of Hungarian citizenship according to the contemporary constitutional reforms and legal practice only took place in 1879. It is a major milestone in Hungarian citizenship law, since it also incorporated in its system the cases of acquisition and loss of citizenship. The law contains detailed provisions on how the legal relationship between the citizen and the state could be established and terminated. The objective of the law was to make the system of citizenship clear and transparent.
\end{abstract}

Keywords: legal history, constitutional law, citizenship, naturalization, loss of citizenship, acquisition, multiple citizenship, Naturalization Committee, parliamentary debate, absence, marriage, national status, dual monarchy

The antecedents of the first Hungarian citizenship law date back to the period of the Revolution and War of Independence of 1848. The bill submitted to the Parliament of 1847/48 already contained the conditions for the acquisition and loss of citizenship. ${ }^{1}$ Due to the importance of the bourgeois transformation, however, the detailed debate of the proposal was subsequently taken off the agenda. Boldizsár Horváth, Minister of Justice, submitted another proposal in 1868, but this did not become law either, as it was not even debated by the Parliament.

Only after settling the most important issues of the age of dualism did the legislators consider the time as appropriate for the legal regulation of the question of citizenship. 


\section{Archival Sources of the Citizenship Law of the Dual Monarchy (Act 50 of 1879)}

When examining the history of citizenship law, in addition to secondary sources, we must give some attention to the primary sources available in the collections of the Parliament and various archives, most importantly the Hungarian National Archive.

The bill drafted for debate in the Parliament was received by the Minister of the Interior on August 21, 1879 (under number 38607). ${ }^{2}$ György Lukács, Ministerial Councilor, sent a letter to the Prime Minister and attached the bill on the loss and acquisition of Hungarian citizenship, which had been formulated in the negotiations between the Minister of Justice and the Minister of the Interior. Some provisions of the bill were subsequently amended, and therefore the ministry attached a warrant explaining that the Minister of Justice had proposed further modifications. $^{3}$

As concerning the bill, the Minister disapproved some of its aspects. Owing to the agreements on Section 11 and 21 of the bill, he deemed it necessary to insert the following provision in Section 31. In order to keep a record of the related details, decisions on naturalization were to be communicated to the Prime Minister on a case-by-case basis. Furthermore, he did not accept the wording of Section 47 saying that "those individuals who have been implicitly regarded as recognized citizens in the legal practice so far, shall preserve their status unless they will attest within one year as from the Act of the Parliament taking effect that they intend to preserve their foreign citizenship." According to the Minister, this rule was not adequate, as it could not be trusted to a person's will that "he should be a Hungarian citizen or not, because [...] it would induce that those being liable to or having been enrolled to military service could exempt themselves or their sons from this liability with a simple declaration asserting that they wish to keep the allegiance to their former homeland as without being able to prove the preservation of the foreign citizenship by means of their passport or of any other document." ${ }^{\circ}$ In the minister's opinion, this corollary was not to provide the bill with a retroactive force, but to make the prevalent practice more precise, as well as to facilitate the work of the competent authorities in the interim period. Finally, he wanted to modify the criteria of obtaining citizenship. ${ }^{6}$

Thus drafted, the bill was sent to the Minister Resident in the Royal Court in Vienna to have him request the pre-sanction of the bill, which then could be propounded to the parliamentary debate with the following caption: "Deferential propoundment to His Majesty, Emperor and Apostolic King by Kálmán Tisza, Royal Prime Minister of Hungary questing supreme permission to put the bill on the acquisition and loss of Hungarian citizenship forward in the Parliament for constitutional debate." 
The justification in the letter argued that in Hungary the issue of citizenship had still not been regulated by law, and to make up this deficiency a bill had been drafted as agreed on by the Minister of Justice, and approved by an earlier meeting of the Cabinet Council. ${ }^{8}$ It introduced the most essential provisions of the bill. Citizenship could be acquired in four ways: by descent, legitimization, marriage, and naturalization. This latter case was given a detailed discussion as one that could acquire Hungarian citizenship if the person in question had been a foreigner, or could obtain a naturalization certificate from the competent authorities, or was awarded with a royal diploma of naturalization, and also took the oath of allegiance. It was emphasized that Section 8 listed the conditions to be met if one wanted to be naturalized by means of an authority certificate. ${ }^{9}$ Such documents could be issued by the Hungarian Minister of the Interior, the Ban of Croatia, and the National Authority of the Border Region. ${ }^{10}$ To ensure the adequacy of registration, the Prime Minister was to enter every single case of naturalization in a separate ledger. From the date of taking the oath of allegiance, any person naturalized in this way was considered to be a Hungarian citizen, yet some restrictions were conceived as necessary to be posed on them: they could not be members of the legislature immediately, and ennobled by the pure act of naturalization.

The letter also expounded the passages on the loss of citizenship. Citizens under the liability to military service could only be dismissed from allegiance if they were granted an emigration permit by the joint Minister of War. It highlighted that those persons who had been neither exempted from such liability, nor enrolled to military service could only be dismissed if the object of emigration was not the disengagement from liability to military service. ${ }^{11}$ In wartime the right to make the related decision was to be reserved to the king. There was also to be a registry of dismissals. The letter specifically referred to Sections 38 to 45 , which comprised the regulations for recovering citizenship, as well as for re-naturalization.

One of the final clauses stipulated that the act would not affect the citizenship of those who had obtained naturalization certificates before the effective date of the Act. Hungarian citizen would be those people who

\footnotetext{
have resided on the territory of the countries under the Hungarian Crown for at least ten years without interruption before the effective date of this Act, even if in more than one location, and entered into the tax registry of any domestic township, unless they provide evidence within one year as from the effective date of this Act that they have maintained their foreign citizenship. ${ }^{12}$
}

The Minister justified the addition of this latter deadline to the bill by arguing that a person who had long been living in the territory of the Hungarian state and benefited from "all the rights of national residents" 13 should not subsequently avoid fulfilling the related civil obligations. Naturally, the King approved the re- 
quest, and empowered the Prime Minister to put the bill forward in the Parliament. ${ }^{14}$

Prime Minister Kálmán Tisza personally contributed to Hungary's first law on citizenship ${ }^{15}$ and the bill was discussed and opined by the Naturalization Committee of the Parliament.

\section{Work in the Naturalization Committee}

In 1879 Hungarian legislation deemed it was time to settle the issue of citizenship once and for all. The previous years had witnessed an upsurge of legislative acts striving to legally settle the question of who should belong to the states of Europe (Germany Act of 1870, Switzerland Act of 1876, Italy Civil Code of 1865, Great Britain Act of 1870). This international wave was joined by Hungary, when on 8 October 1879 Prime Minister Kálmán Tisza introduced the bill on the "acquisition and loss of Hungarian citizenship" to the House of Representatives. The justification of the bill identified as main reasons the need for, on the one hand, the clearing up of a rather confused legal situation, and on the other hand the protection of the interests of the Hungarian state. ${ }^{16}$ The proposal law was intended to fill in a substantial gap, since the loss of citizenship, apart from the case of a Hungarian woman marrying a foreigner, had not been regulated by national laws so far.

The House of Representatives, immediately upon the Prime Minister's proposition, set up a 15 -member naturalization committee on the very same day. The representative in charge of the issue, Jenő Péchy praised the proposed act as one that is

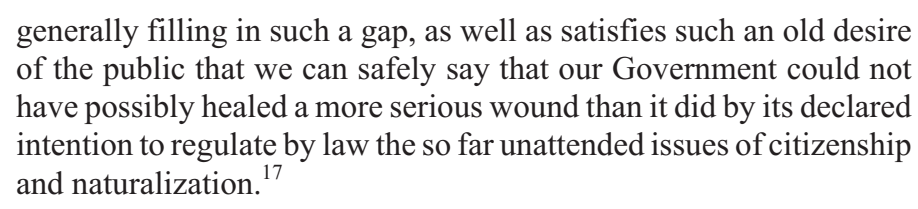

generally filling in such a gap, as well as satisfies such an old desire of the public that we can safely say that our Government could not have possibly healed a more serious wound than it did by its declared intention to regulate by law the so far unattended issues of citizenship and naturalization. ${ }^{17}$

As concerning the principles of the bill, Jenő Péchy specified three essential "governing conceptions": equality, the principle of the one and the same citizenship, and "the special Hungarian nature." 18 After the ceremonious address by the committee presenter, Nándor Szederkényi, an opposition representative disclosed his observations to the Parliament. In his contribution he criticized the government for trying to put the bill through the Parliament with excessive haste. "This bill is not debated in accordance with its significance," $" 19$ and owing to the brevity of time ${ }^{20}$ the representatives could not make serious inquiries. He joined issue with Jenő Péchy about "the special Hungarian nature" of the bill, when considering the proposition from another point of view, he declared: 
... this bill is anything but of Hungarian nature. This bill fosters general cosmopolitanism, establishes - what is the most injurious to Hungary - common soil with Austria, against which the Hungarian state and Hungarian citizens always object to. ${ }^{21}$

At this point, Representative Szederkényi uttered his opinion that the part of the proposition related to the naturalization and re-naturalization of foreigners primarily produced "exceptional conditions with Austria." In this respect he motioned that it should not be the monarch, but the legislative body that was to be vested with the right of naturalizing foreigners, and those persons naturalized in this way should not be allowed to be members in the Hungarian legislation or the Hungarian Crown Council; furthermore, in order to reinforce the special Hungarian nature of the act, the addressee of the oath of allegiance should be the King of Hungary instead of "His Majesty, Emperor and Apostolic King." He even proposed to eliminate the passage of Section 32 outright that was the most ardently challenged in the course of the whole parliamentary debate for stipulating that if Hungarian citizens keep away from the monarchy for ten years without interruption and permission, they should lose their Hungarian citizenship (Szederkényi suggested applying this provision only to foreigners having been naturalized, while in the case of "natives" forfeiture of the title should be judged according to their merits). ${ }^{22}$

On the basis of the Resolution by the Naturalization Committee No. 1685 passed on 8 October the bill was discussed, and the related report was drafted at the meeting held on 18, 19 and 20 October. The Prime Minister's justification attached to the bill was meant to be conclusive about the requisiteness of the proposal, since the lack of such legal regulation could be felt even by the general public for years. ${ }^{23}$ Substantial amendments were made only to Section 10 and 11 stipulating that the right to grant Hungarian citizenship to persons in the country of Croatia and Slavonia, as well as in the Border Region should be vested to the Hungarian Cabinet Council, specifically the Prime Minister.

The bill was drafted with an eye to the unity of the Hungarian state and in conformity with similar laws of the Western European countries. The principle of equal rights was also taken into consideration. In accordance with Section 48, the Border Region as a separate authority would be organized to a term until its territory was administratively unified with the country of Croatia and Slavonia. The Committee also made some concessions with regard to the acquisition of citizenship by adopted foreigners (Section 8$)^{24}$

Dissents were attached to Sections 1, 15, 30, 32 and 37. New Hungarian citizens could not be citizens of other states at the same time, except for the members of the royal house, because it would have gone against the idea of Hungarian statehood in the face of emphasizing the "individuality of the Hungarian state" and accentuating the "Hungarian nature of citizenship." 25 
The idea of multiple citizenship was not conceded, as it could have occasioned political misuse, and generated enormous tangles and "complications" also in the field of private law. There existed obligations that could have been evaded in this manner (e.g., military service). In the event a person had been the citizen of two states being at war with each other, he would have had to be neutral in the conflict, or betray his oath of allegiance to one or the other of the countries. Hungary and Austria were exceptions, since there were 40 to 50 Austrian families that also held Hungarian citizenship. According to the bill, they were required to declare their decision within one year "whether they want to preserve their Hungarian or Austrian citizenship." 26 As a principle, the exclusivity of Hungarian citizenship had been accepted by the bill on citizenship drafted by László Szalay in 1847. Therefore, it was requisite to stipulate in Section 20 that "Hungarian citizenship shall be lost by those entering the tie of another state, ${ }^{27}$ while Section 37 was intended to be completely omitted. The committee also wanted to regulate that persons naturalized by means of the royal diploma should not be the members of the legislature immediately. Besides, the committee's minority opinion called for the cancellation of Sections 30 and 32, because such provisions disagreed with the principle that Hungarian citizens, just like their American or English counterparts, could preserve their Hungarian citizenship everywhere and for all times until they voluntarily renounced it. ${ }^{28}$ This could not be in the interest of the Hungarian nation.

Under Section 30 of the bill, persons living abroad would lose their citizenship if they did not return in response to the so-called "gazette summons" initiated by the government at its own discretion. Apart from the restriction on personal freedom, this solution lodged too a large power in the hands of the government. Also, gazette summons were not regarded as expedient because it could not be required from Hungarian citizens residing abroad that they read official gazettes. In accordance with Section 32, citizens living abroad for more than ten years could return "only as foreigners." 29 Such a provision was found to be justified by the committee for countries with overpopulation (Germany). On the other hand England constituted a situation where the period could also be characterized as one of overpopulation, but no one was divested from their citizenship in their absence. Thus, the legislators opined that such regulation would have been proper neither in Hungary, because "the elimination of every single citizen can be considered as a loss." ${ }^{, 30}$

Another reason why the Committee was unwilling to approve the provision was that it would deprive not only the citizen of his national status, but his family residing with him, as well. For example, if a Hungarian citizen got married abroad and had children, who were - for the time being - also qualified as Hungarians, and then the father happened to stay abroad for ten years, every member of the family would lose their citizenship. The representatives viewed this part of the proposal pronouncedly erroneous as owing to the fact that if someone lost his citi- 
zenship without either being willing to be a subject of another state, or being the citizen of any other state, then he would be a foreigner to the whole world. The minority opinion held that no one might wish such a grievous destiny to any Hungarian citizen. ${ }^{31}$

At the meeting of the House of Representatives held on 5 November Representative Aladár Molnár submitted one, while Representative Károly Csider put forward two proposals that the committee debated on the same day. Aladár Molnár motioned that Paragraph 2 of Section 37 be cancelled, and naturalization under Section 17 be given effect by allowing the person naturalized to be immediately the member of the national legislation, only if the citizen could prove that he had been dismissed from the state he had belonged to, and on condition that such dismissal did exist under the laws of the state in question. Later, Aladár Molnár amended his proposal by suggesting that it should be applied not only to Section 17, but to the whole act, as well. The Committee did not accept either the original, or the amended proposal, saying that "it would disagree with an already established principle of the bill, the possibility of dual citizenship." ${ }^{32}$ Yet, the Committee supported that immediate membership in the national legislature should be restricted in the ten years required by Section 15 of the Act as corresponding to the proposal. Consequently, they proposed the insertion of a new passage after Section 17.

\footnotetext{
The unusual extent effect of naturalization under Section 17 whereby a person thus naturalized may become a member of the national legislation immediately after naturalization is to be applied only, if the person naturalized proves that he has been dismissed from the state he belonged to, provided that such dismissal is permitted under the laws of the given state. ${ }^{33}$
}

By his proposal Representative Károly Csider intended to achieve the insertion of the following new passage after Section 42: "As in accordance with Section 9, applications for naturalization shall be submitted to the authorities being competent under the Applicant's belonging to the township tie specified in Sections 39, $40,41,42 .{ }^{34}$ The Committee accepted the motion, though according to their opinion the proposed regulation had been implicitly in the bill. Therefore, admitting the proposal, they inserted an additional Section following Sections 42. This passage of the bill asserted that in cases under Sections 39, 40, 41, and 42 any application for re-naturalization should be submitted to the authorities being competent under the Applicant's belonging to the township tie, and specified in Section 9. In the event there was no such a township tie, because the Applicant's admission was in progress, he had to submit his application to the authority that had previously undertaken his admission. 
In his second motion, the representative requested to insert after Section 43 that the time period of the citizenship having been lost earlier should be counted in the ten years that was required from the person naturalized to be the member of the national legislation by Section 15 of the bill. This regulation would have been in effect only for re-naturalized persons, and the motion was also supported by the committee. In general, they backed up the idea to provide re-naturalized persons with more favorable conditions as concerning the practice of political rights.

On 30 October Pál Hoffmann and Sándor Dárday presented new proposals for amendments to the Naturalization Committee. The proposals concerned Section 3, 4, 5, and 19 of the bill. First, Pál Hoffmann's motion was discussed, but they disapproved even its structural framing, as it intended to combine the above-mentioned passages in two paragraphs.

The first proposal considered the issue of who were to be regarded as Hungarian citizens:

- members of the royal house (so much it stood to reason to the Representatives as they did not want to concretize it);

- any Hungarian citizen's legitimate children, even if they were born abroad;

- those legitimized;

- those acquiring citizenship by marriage.

The second proposal then put some supplementary lettering to Section 3 (e.g., following the word "acquire" the expression "Hungarian citizenship" was to be inserted in the bill). However, Representative Dárday's motion for stylistic amendments was not accepted.

\section{The Detailed Parliamentary Debate of the Proposition}

What followed was the debate of the bill in the House of Representatives. Nándor Szederkényi in his opinion presented earlier was joined by Lajos Mocsáry, who in his speech declared:

I cannot accept the bill in question as a subject of detailed debate, especially with respect to the fact that this bill contains elements whereby I regard the notion of Hungarian statehood ... being contested ... and I fully share the opinion of my honorable friend, Nándor Szederkényi that here a certain novel contrivance, namely the principle of common Austrian Hungarian citizenship hs emerged, and came to the foreground. ${ }^{35}$ 
He reckoned to reveal deviation from the current legal practice in the non-observance of two particular legal principles:

... no Hungarian citizen may be deprived of his civil rights until he has requested the same. This is one of the essential characteristics of the Hungarian conception. While cardinal issue is that naturalization is a right reserved not to the monarch, but to the Parliament. ${ }^{36}$

As concerning Section 32, it was Mocsáry, who could put into words most unequivocally the objective of the government as conceived by the opposition:

Are you aware of the consequences of enacting this law? You are turning Kossuth himself an exile. Because if he should come back, his return will not even enable him to be elected a representative. I personally hope that the nation will not expatriate the faithful from her heart, but expatriate those who want to exile Lajos Kossuth, those who do not shrink from extending the scope of common affairs, those who do not shrink from introducing such a bill to debate. I myself cannot accept the bill as a subject of detailed debate. ${ }^{37}$

On behalf of the Government, it was Minister of Justice Tivadar Pauler and Prime Minister Kálmán Tisza who briefly responded to opposition claims. Throughout the detailed debate, the possibility of dual citizenship also heated the passions. According to Imre Veszter, "there are hardly any issues in private law that would not turn into most diverse and labyrinthine complications under the unrestricted retention of dual citizenship, ${ }^{, 38}$ and to resolve this situation he suggested that persons entering the tie of another state should lose their Hungarian citizenship and that foreigners should not be naturalized in Hungary until they proved their dismissal on condition that such dismissal did exist under the laws of their homeland; and if the country in question did not concede the legal institution of dismissal, such foreigners should declare in the Hungarian oath of allegiance "that during being the citizens of the Hungarian state: they will not exercise the rights arising from their former citizenship." 39

Pál Hoffmann moved to settle the same issue with a quintessential amendment: "allegiance binding to any foreign state cannot be on terms with the capacity of being a Hungarian citizen." ${ }^{40}$ In his response, Kálmán Tisza explained:

... the Hungarian state would be in a - I do not want to say - subordinate, but in any case worse situation compared with other states, if she declared that whoever is the citizen of another state, cannot be the citizen of the Hungarian state ... and when considering the prestige of the state and the dignity of the state, I hold it as more appropriate ... if a state enounces: everyone can remain my citizen until I rule otherwise, regardless of what other countries may do with them. ${ }^{41}$ 
This argumentation proved to be imposing, and the original wording that had generated much controversy was maintained: "Section 1: Citizenship in the countries of the Hungarian Holy Crown shall be one and the same."

The next focal point of disagreement surfaced with the debate on the legal institution of naturalization by means of a royal diploma for outstanding merits. From the side of the opposition, the conception was first challenged by Albert Apponyi. In his speech, he explained that the introduction of the new legal institution would have constituted a break with the old tradition of public law, since it gave rise to a way of acquiring citizenship from which the Parliament would be excluded; the initiative lay in the hands of the government, while the act was made effective as sanctioned by the royal diploma. In the evolving debate it was Aladár Molnár who could put the problem the most clearly:

\footnotetext{
The question ... is who should grant this benefit bestowed for merits, and who is to judge those merits? According to the proposition, it is the Government, and under their proposal the monarch: in Count Apponyi's motion, as corresponding to the long established practice, it is the Parliament, whose resolution shall then be sanctioned by the monarch. ${ }^{42}$
}

Opposition debaters argued by listing foreign examples, and envisioned the "dreadful" picture of the native Hungarian rendered to minority status in his own legislative body. ${ }^{43}$ In addition, all their speeches reflected the underlying principle of the opposition, which was stressed throughout the whole parliamentary debate: struggle against the increase of Austrian influence.

The governmental side characterized the proposition as a practical device to award outstanding merits instantly, and in order to "calm" down the opposition they emphasized the guarantee ensured by the supervision of the government by the Parliament. After that, the issue was decided upon by roll-call voting that brought about a majority for the original proposition. ${ }^{44}$

Discussions on the right of the Ban of Croatia to grant citizenship were accompanied by an exceptionally heated debate. In accordance with Section 10 of Act 30 of 1868, often mentioned as the Croatian-Hungarian Compromise, "as concerning the issues of citizenship and naturalization, there shall be common legislation, but the execution of such regulations shall be reserved to the countries of Croatia-Slavonia and Dalmatia." In the course of the detailed debate of the law on citizenship, however, the majority of the Naturalization Committee presented such a draft to the representatives that would assign the execution to the Cabinet Council and the Prime Minister across the whole of the territory of the Hungarian Crown. This contrasted with the original wording by the Government, as well as with the above-quoted regulation of the law. In his speech, the presenter touched upon the issues of execution, state sovereignty and the relevant points in the Cro- 
atian-Hungarian public law agreement. Finally, after a heated debate the green light was given to the original governmental conception, that is the naturalization right of the Ban of Croatia. ${ }^{45}$

As has been mentioned above, it was Section 32 that generated the most heated passions and ardent opinions, as it intended to introduce the loss of citizenship after 10 years of absence to Hungary's law. The opposition designated the proposition as an open governmental assault against political emigrants, which at the same time determined the orientation of the evolving debate. The weight of legal argumentation was dwarfed by political speeches and contributions echoing apprehension for the nation. ${ }^{46}$ The governmental side tried to soothe the opposition (and its own conscience) by asserting that the retention of citizenship was bound to a simple declaration that, owing to its insignificance, could not seriously conflict even with the principles of emigrants. On the opposition side, this approach was confronted with the words by Ignác Helfy, who observed, "When a political conviction or a political act is concerned, it cannot be the question whether it is large or small. In political matters, it is not the largeness of the act that raises importance, rather the inherent humiliation. ${ }^{, 47}$ At the end of the passionate debate that tended to involve personal remarks, the opposition presented a united front for Ernő Simonyi's amendatory motion. "Section 33: Provisions of Section 32 will not apply to those having emigrated for political reasons."

On behalf of the Government, the Prime Minister, Kálmán Tisza took the floor, and asked the Honorable House to disapprove the proposal. He argued that the institution of re-naturalization was regulated in Section 41 of the bill, and on the basis of the related provisions persons returning to Hungary could automatically regain their lost citizenship by being admitted to the tie of any township; consequently, the opposition's accusation of expatriation was not true. Eventually, Tisza tried to highlight the underlying logic of the government's proposition in the summary of his speech:
As far as I am concerned, I consider it [i.e., Simonyi's amendatory motion] as one that cannot be accepted, because firstly ... citizenship rights can be actively exercised only by persons that are in the country ... and secondly because - as I have said - everywhere in the world those who want to exercise citizenship rights may disapprove some laws, but are nevertheless obliged to acknowledge being sub- ject to such laws ... thirdly because ... it may indeed grant liberty of those who act against the existence of the Hungarian state, not only condemning the laws of the country, but subverting her existence. I myself will not approve the motion, and implore the Honorable House far as not to approve it ..., but omit the passage proposed. ${ }^{49}$

The majority in the House of Representatives did listen to their Prime Minister again, and in the roll-call vote, by a vote of 193 representatives out of the 442 be- 
ing validly present - since the Chairman did not vote -, they dismissed Ernő Simonyi's amendatory proposal with 141:52, and finally, the original wording by the government was accepted.

The remaining sections of the bill were discussed by the House of Representatives without notable disputes, and at last on 8 November 1879, after the third reading, the representatives approved the bill with 88 yeas and 73 nays; then it was sent over to the Upper House for discussion and consent.

Again, the bill was discussed, and after the general and principle debate it was approved. This procedure was followed by the detailed debate, wherein the Upper House accepted the title of the act, as well as Sections 1 to 3 with no modification. After reconciliation with Sections 5, 6, and 3, Section 4 was proposed to be accepted as follows: "By means of legitimization, citizenship may be obtained by the illegitimate children of Hungarian citizens born to foreign women. ${ }^{" 50}$ Sections 5 to 13 were also approved without any amendments. For taking the oath (affirmation) specified in Section 14, the Upper House referred to the significance and solemnity of the act, and wished the form of the oath to be conceived accordingly. When making reference to His Majesty's name, they proposed to use the address of "His Majesty, Emperor and King, Apostolic King of Hungary" instead of "His Majesty, Apostolic King of Hungary." Section 29 were accepted with no modifications. In the second line of Section 30, they intended to omit the conjunction "also" from the text, since they deemed it as confusing to comprehension. The Upper House did not change Sections 31 to 47, either. On the other hand, in the fourth and fifth line of the second paragraph of Section 48 they wished to replace the words "Croatian Border Region" with the expression of "Croatian-Slavonian Border region. The next sections were accepted without any amendments, as well. After that, the bill with the above amendments was accepted by the Upper House, and "on this decision, the House of Representatives shall be informed in order to hold the constitutional debate, as well as to obtain their kind consent." ${ }^{, 52}$

The Naturalization Committee discussed the proposals on 20 November and approved the amendments to Sections 4, 30, and 48, as well as the form of the oath. This latter modification was accepted only because it corresponded to the legal practice of the time. ${ }^{53}$

In the form of a legislative act, the authentic text of the accepted bill was sent to the Prime Minister by György Lukács. ${ }^{54}$ Indeed, he forwarded the bill that had been worded by the Naturalization Committee. In this proposition, amendments having been approved by the House of Representatives and the Upper House were entered as handwritten. ${ }^{55}$ Apart from some minor stylistic changes, the Upper House approved the whole text of the bill, which then was submitted to Emperor 
Franz Joseph; he sanctioned the bill on 20 December 1879, and it came into force on January $5,1880 .{ }^{56}$ The new act completely corresponded to conditions in Hungary in the period. ${ }^{57}$

\section{Acquisition of Citizenship}

In Hungarian constitutional history the system of citizenship was based on the right of lineage, which meant that children inherited their fathers' citizenship. The majority of Hungarian citizens in the second half of the nineteenth century were natural born Hungarians, who had acquired their citizenship by way of lineage.

The first citizenship law defined the following cases whereby Hungarian citizenship could be acquired: descent, legitimization, naturalization, and marriage. ${ }^{58}$ This listing in the law was complete; in other words there were no other ways of obtaining citizenship. ${ }^{59}$ According to some researchers, additional ways also included retrieving and acquiring citizenship on the basis of "an old right" (or "implicitly"). ${ }^{60}$ After the framing of the law, the number of legal titles further increased. Act 4 of 1886 introduced the institution of re-admission for the large number of those re-settling in Hungary. ${ }^{61}$ Hungarian citizenship could therefore be acquired in a direct and an indirect way. In the first group the only possibility was birth. These citizens could be called "native Hungarians" (Hungari nativi). ${ }^{62}$ In the second group belong the received or naturalized Hungarians (Hungari recepti), who obtained citizenship by way of legalisation, naturalisation or marriage. ${ }^{63}$

The voluntary intention originating in one's own resolve, which was among the objectives of the law, was fully asserted in case of naturalization only. ${ }^{64}$

According to Hungarian citizenship law, entering state service did not automatically result in obtaining citizenship. The only exception was when the moving into the country was for the purpose of settling down permanently and the acquisition of residence in a township was already under way. ${ }^{65}$

The ministerial justification of the law specifically mentions the German regulations of 1870, in harmony with which the bill of 1879 was drafted. The German citizenship law defined the legal titles of acquiring citizenship in a way that was identical with the Hungarian law. 


\subsection{Descent}

Anybody who was a legitimate child of a Hungarian father, or who was born to a mother of Hungarian citizenship was also a Hungarian citizen. ${ }^{66}$ This rule was also applied if the place of birth was abroad. ${ }^{67}$ This legal provision had been in effect even before the passing of the citizenship law, since such people were called the "sons of the home country" (nativi Hungari, patriae filii). ${ }^{68}$ If a man of Hungarian citizenship married a foreign woman, their children were Hungarian citizens, since the wife lost her original citizenship by reason of the marriage. The children would also be Hungarian citizens if the mother was a Hungarian citizen and the father a foreigner. Children born out of wedlock by a foreign mother would also be considered as natural born Hungarian citizens, if they were legitimized subsequently. Legitimization (marriage and royal legitimization) was basically the subsequent recognition of citizenship based on birth. ${ }^{69}$

According to Hungarian constitutional law, if somebody lost his or her Hungarian citizenship, this would never be automatically regained. In such cases citizenship would have to be re-acquired. ${ }^{70}$

There were some states (England, Denmark, Portugal, etc.), which recognized children born on their territories as their own citizens on the basis of the territorial principle (jus soli), regardless of what citizenship their parents had. The Hungarian citizenship law only allowed this principle to be asserted in some extraordinary cases. Such a case was, for example, if a child was born in the territory of the country, but nothing was known of the citizenship of his or her parents, and therefore, lineage could not be used to determine the actual citizenship of the child. ${ }^{71}$ The same principle had to be used in case of foundlings whose parents were not known at all. ${ }^{72}$ In both cases it was presumed that the parents were Hungarian citizens since the birth took place on the territory of the Hungarian state. Such a presumption, however, could be disproved. ${ }^{73}$

\subsection{Marriage}

Citizenship could be obtained by way of marriage ${ }^{74}$ if a foreign woman married a man of Hungarian citizenship. In such cases the change in the marital status of the foreign woman ipso facto resulted in the change of her citizenship. ${ }^{75}$ Her new citizenship acquired by way of marriage was not subsequently lost even if she was widowed or divorced. ${ }^{76}$ Naturally, only legally concluded marriages had such legal consequences, since invalid, void, or contestable marriages, according to Section 37 of the law, only had such an effect until the invalidity of the marriage was pronounced by a final judgment of the court. ${ }^{77}$ 


\subsection{Naturalization ${ }^{78}$}

Foreign nationals could acquire Hungarian citizenship by a deed of naturalization or by a royal diploma, as a result of which both they and their descendants would become Hungarian citizens. The institution of acquisition of citizenship by way of a deed of naturalization was also known before 1879, since the Hungarian Royal Minister of the Interior issued such documents from 1867, which also remained in effect after the entry into force of the citizenship law of $1879 .{ }^{79}$

A foreigner who had not acquired citizenship by way of simple naturalization ${ }^{80}$ or by way of a deed of naturalization issued after 1867 could only acquire Hungarian citizenship after 8 January 1880 by way of naturalization under the new law, even if the person had continuously lived on the territory of the country before and exercised the rights of Hungarian citizens.

Hungarian constitutional law recognized two methods of naturalization: simple naturalization and special naturalization. ${ }^{81}$ The emphasis in both cases was on the definite expression of will and acting according to prescribed forms, and therefore, no one could become a Hungarian citizen implicitly, nor could one become a citizen in the absence of certain basic conditions.

The following conditions had to be met for simple naturalization. The applicant had to have unlimited capacity of action, or in the absence of such capacity, his or her guardian's consent had to be obtained. The applicant also had to either be a resident of a local township, or at least the procedure for such purpose had to have been initiated. Communities could not be forced to hold out the prospect of admittance to the township in case of naturalization. ${ }^{82}$ The applicant had to have lived in the territory of the Hungarian state for an uninterrupted period of five years. He had to have been of impeccable conduct, had to have an income or wealth sufficient for maintaining himself and his family, and also had to have been on the list of taxpayers for at least five years. ${ }^{83}$ The law, on the other hand, had no provisions for the examination of the applicant's emotional attachment as to whether he was to become a member of the Hungarian state not only materially and physically, but also morally and spiritually. ${ }^{84}$ In addition, the law did not require a physical or mental examination either. ${ }^{85}$

According to the above conditions, the applicant had to have either unlimited capacity to action or his representative by law (guardian or trustee) would act on his behalf in the procedure. Only persons of legal age and capacity to act were able to request naturalization. Married women living with their husbands could only obtain Hungarian citizenship on the right of their husbands. A married woman could only acquire Hungarian citizenship if she lived separated, or the court had dissolved her marriage, or she was "separated from bed and board," widowed. A legitimate child could request naturalization on the right of his or her father, or on the right of the mother, if she was widowed. A child could also be nat- 
uralized at the request of either the father or the mother, if he or she acted as the child's legally appointed guardian.

The issuance of a promise of admittance to the township was reserved to the powers of the autonomous rights of the village or the town, which could only be practiced under the general decree of the Minister of the Interior no. 44.967/920. Aspects of national interests also had to be taken into consideration. ${ }^{87}$

The five years' domestic residence requirement had to have been fully met. The existence of immovable property had to be evidence by way of an extract from the land registration, movable property by way of an official certificate, and the payment of taxes by way of an extract from the tax registry. ${ }^{88}$ Tax paid by a woman was taken into account for her husband, as was tax paid by the father for his child. Arrears in the payment of taxes were not necessarily a cause of refusal to the application. (The tax payment requirements set forth by the law, however, could not be met by paying the taxes in advance for five years.)

The simple legal fact of adoption, therefore, did not automatically result in the acquisition of Hungarian citizenship, but it did make it easier to meet the conditions. ${ }^{89}$

The naturalization procedure was always initiated by way of an application. The mere satisfaction of the prescribed conditions did not automatically result in the acquisition of Hungarian citizenship; it only opened the possibility to acquire citizenship. ${ }^{90}$ It was the prerogative of the Minister of the Interior to decide who could become a Hungarian citizen. An applicant would only become a Hungarian citizen when they took the oath of allegiance. A deed of naturalization was considered as evidence of the acquisition of citizenship if the date of naturalization was entered on the document by the competent authority. The oath of allegiance had to be taken within one year from the receipt of the writ issued by the authority; otherwise, the applicant's passive conduct caused the loss of the opportunity for becoming a Hungarian citizen. The citizen also had the right, however, to revoke the deed of naturalization in justified cases if the oath of allegiance had not yet been taken. ${ }^{91}$

Naturalization by royal diploma took place only in special and extraordinary cases. Persons could thus receive Hungarian citizenship who had outstanding achievements in the interest of the country, "who have become worthy of Hungarian citizenship in the service of the Hungarian people. ${ }^{, 92}$ The Minister of the Interior proposed to the king who should receive such a diploma without the prospects of admittance to any local township or without having to meet the five years' residency requirement or inclusion in the tax registry. In such cases Budapest was always entered as the place of residence, except if the person thus naturalized received admittance to some other township in the meantime. Even such persons had to take the oath of allegiance, however. ${ }^{93}$ 
It must also be noted that neither simple nor extraordinary naturalization granted a title of nobility. A naturalized citizen could not be elected to the office of keeper of the crown and a person naturalized by deed could only become a member of the House of Representatives after ten years, or a member of the Upper House by way of the Parliament (Act 7 of 1885). ${ }^{94}$

The annexes required by the law had to be attached to the application and certified. The applicant had to submit the documents to the highest official of the local authority according to his place of residence (the sub-prefect of the county or the mayor of the city). ${ }^{95}$ This rule also applied if the applicant received a promise of admission from another township. The officials examined the application in terms of form and content, and then presented the documents, complete with justification, to the Minister of the Interior. If they found the application deficient in any respect, then they called upon the applicant to submit further documentation. If the Minister of the Interior considered the applicant as worthy of Hungarian citizenship, then he issued the deed of naturalization.$^{96}$ Otherwise, he rejected the application and notified the competent authority of his decision. The competent authority would then notify the decision to the applicant: if the decision was favorable, then the place and time for taking the oath of allegiance was given; otherwise, the documents submitted were returned along with the letter of rejection. ${ }^{97}$ The wording of the oath of allegiance was the following: "I, N. N., swear by the living God (affirm) that I shall be faithful to His Imperial and Royal Majesty, the Apostolic King of Hungary, and to the Constitution of the countries of the Royal Crown, and shall loyally perform my obligations as a Hungarian citizen." ${ }^{98}$ A documentary record was taken of the oath, which was to be signed by the applicant, who subsequently received the deed of naturalization and his personal documents. The authorities had to notify the Minister of the Interior of the taking of the oath. The Minister by turn would notify the Prime Minister and the Royal Hungarian Bureau of Statistics. ${ }^{99}$

People who had lived for a period of at least five uninterrupted years before the coming into force of the first citizenship law on the territory of the Hungarian Crown and were on the list of taxpayers in the registry of a township were also considered to be Hungarian citizens, provided that they did not notify the competent authority according to their place of residence that they wished to maintain their foreign citizenship. ${ }^{100}$

Austrian citizens could only be naturalized in Hungary, like Hungarians in Austria, if they were first dismissed from Austrian or Hungarian citizenship, respectively, in accordance with the Treaty of $1870 .{ }^{101}$ 


\subsection{Favored naturalization (re-naturalization) ${ }^{102}$}

The main difference between favored naturalization and the previously described procedure was that the former could only be applied to originally Hungarian citizens, while naturalization was a procedure reserved for foreign citizens. Not all former Hungarian citizens could use this easier procedure. Those who were excluded from Hungarian citizenship by an authority's decision did not qualify. Such persons had seriously violated their obligations as citizens. Those who had lost their Hungarian citizenship by way of legitimization, and were therefore considered as foreigners on the basis of the citizenship of their fathers, also belonged to this circle. ${ }^{103}$ A person could acquire a new citizenship both by way of naturalization and re-naturalization, but there was still a significant difference between the two situations, since in the latter case, only the legal ties had been broken "between the Hungarian state and its son, who lost his Hungarian citizenship, yet the ethical ties were not broken."104

Several groups could be established within the circle of those subject to favorable naturalization. A person who had lost his citizenship by way of dismissal or absence and did not obtain another citizenship could be re-naturalized as a citizen even if he had not returned to the country in the meantime. Such a person would be given admittance to his former township upon re-naturalization. If a person obtained a new citizenship, he could only be re-naturalized if he returned to the territory of Hungary and a township promised to admit this person as a resident. In the latter case, the Minister of the Interior had no room for discretion, unlike in the former situation.

Additional advantages were provided by the citizenship law to women and minors. A woman who had lost her citizenship not independently but by way of the dismissal or absence of her husband, or by way of marriage to a foreigner, was given Hungarian citizenship, provided that her marriage had terminated, and she had already initiated the procedure for admittance to a township. A minor, on the other hand, who had lost his citizenship by reason of his father's dismissal or absence was re-naturalized as a Hungarian citizen when either he became of legal age or his father died, provided that his admittance to a township was under way. ${ }^{105}$

Documents proving that such a person had formerly been a Hungarian citizen had to be submitted with the application. ${ }^{106}$ In all other respects the procedure was the same as in case of simple naturalization. ${ }^{107}$

The ten-year rule for becoming a member of the legislature did not apply to re-naturalized persons, except if they originally acquired their citizenship by naturalization not more than ten years before. ${ }^{108}$ 


\subsection{Naturalization of re-settlers in large numbers}

The above provisions applied to emigrants and their immediate family members, and did not take into consideration the return of the descendants of Hungarians, who had left the country several generations before. To fill in this gap, Act 4 of 1884 extended the provisions of the citizenship law relating to favored naturalization. ${ }^{109}$ The date when the applicant's forbears left the country could not be taken into consideration. The township to which the applicant was to belong to had to be established by the authority, and several applicants intending to settle in the same place could submit a joint application for naturalization. ${ }^{110}$

\subsection{Legitimization}

An illegitimate child born to a Hungarian man and a foreign citizen woman could acquire Hungarian citizenship by way of legitimization. The subsequent marriage of such a child's parents was to have the result on the child's citizenship as if they had been born in wedlock. ${ }^{111}$ A naturalized father's citizenship did not extend to his legitimized children, if they were already of legal age. In such a case the children were only able to obtain Hungarian citizenship by way of ordinary naturalization. Legitimization was to have a retroactive force to the date of the child's birth. ${ }^{112}$ The precise order of procedure was not defined by the law; therefore, subsequent marriage and royal legitimization had the same effect. ${ }^{113}$

It can be observed that in subsequent citizenship laws less and less room was available for state interference. One by one, the reasons used for the enforcement of the peculiar legal principles of the age were removed from among the conditions.

\section{Notes}

1 Károly Kisteleki, “Az állampolgárság a dualizmus idején” [Citizenship at the Time of the Dual Monarchy], Állam és Jogtudomány, (1996-1997): 42.

2 Országos Levéltár Iratai [Documents of the National Archives] (hereinafter: OLI): 1879-I - B - 89 (1879 - I - B - 2444), Document no. 2444, Subject no. 38607. (August 21, 1879), postscript no. 2485.

Issued in Budapest, August 13, 1879 under no. 2319. OLI: 1879 - I - B - 89.

OLI: 1879 - I - B - 89, Document no. 2319.

Ibid.

Received by the Royal Ministry of the Interior on August 21, 1879 under 38607.

OLI: $1879-\mathrm{I}-\mathrm{B}-89$, PM's document no. 2444.

8 OLI: $1879-$ I - B -89, CC's document no. 38 . The related abstract reads the following. The Prime Minister introduced the bill on the acquisition and loss of Hungarian citizenship to the 
Cabinet Council; the Council approved the bill, and authorized the Prime Minister to put it forward in Parliament as assented by the King. In the absence of the Cabinet Council's notary, the document was signed by the Department Councilor.

9 From among these, the Minister emphasized the requirement of residence in the country for at least five years without interruption, as well as to have been registered in the tax registry of any township for at least the same period. OLI: 1879 - I-B - 89, 2485. I. B. document no. 89/2444.

10 A bill was also drafted to settle citizenship in the country of Croatia and Slavonia. Belügyminiszteri Általános Iratok [General Documents of Minister of the Interior] (hereinafter: Bm. Ált. Iratok) K 150 II. no. 48295.

11 Any exception to this regulation was regarded as justified by the Minister only if the aim was the acquisition of Austrian citizenship. OLI: 1879 - I - B - 89, 2485. I. B. document no. $89 / 2444$.

12 Ibid.

13 Ibid. Appendices to the letter: the draft and justification of the bill on the acquisition and loss of Hungarian citizenship (2 copies), the draft of the supreme decision (1 copy).

14 Dated. Vienna, August 27, 1879. Ibid.

15 Károly P. Szathmáry, ed., Az 1878. évi október 17-ére hirdetett országgyülés képviselöházának naplója [Journals of the House of Representatives of the Parliament Summoned to October 17, 1878] (hereinafter: Journals), vol. VII, (Budapest, 1879), 213.

16 Károly Kisteleki, ibid., passim.

17 For J. Péchy's speech, cf. Ibid., Napló [Journals], vol. VII, 268.

18 As concerning the special Hungarian nature, Jenő Péchy's speech argued for the legal continuity of the previous Hungarian practice, the principle of descent (ius sanguinis, the principle of kinship): "on the one hand, the bill will not immediately divest our homeland's citizen that has emigrated, and probably entered the ties of a foreign state from his citizenship; on the other hand, it will not give up the children of citizens that has inclined - partly owing to the conditions - towards foreign lands, and been perhaps forgetful of their homeland, and these children will be reclaimed by Hungary, just like any legitimate children of Hungarian citizens and illegitimate children of Hungarian women, as their homeland always hopes to reckon upon them with good reason, and regards them as Hungarian citizens, even if their place of birth is in a foreign land, because it is just the same; 'Eagles beget only eagles'. And Hungarian blood cannot deteriorate to affect the descendants; not other than Hungarian can part from the breasts of Hungarian mothers, no matter how northern fog or the searing southern sun hailed his coming to life." J. Péchy: Ibid., Napló [Journals], vol. VII, 269.

19 Ibid., Napló [Journals], vol. VII, 270-271. Contribution by Nándor Szederkényi.

20 "This bill was submitted on the $8^{\text {th }}$ of this month, this year, but the government made the committee to debate it on the $18^{\text {th }}$, and in ten days, thus today has been presented to the House." Ibid., Napló [Journals], vol. VII, 270.

21 Ibid., Napló [Journals], vol. VII, 271.

22 Joined by eleven representatives, Nándor Szederkényi introduced his proposals to the House as a vote, requesting that the House of Representatives should recommit the bill to the Naturalization Committee with a view to the objections made by him "to amend, correct and reframe it in the future." The vote as proposed did not receive a majority. Ibid., Napló [Journals], Volume VII, 273.

23 Képviselöházi irományok [Documents of the House of Representatives] (hereinafter: K. i.) 1878-81, no. 338, 264.

24 Ibid., K. i. no. 338, 264-266.

25 Ibid., K. i. no. 338, 276.

$26 \quad$ Ibid., K. i. no. $338,277$. 
Ibid., K. i. no. 338, 277.

Ibid., K. i. no. 338, 278.

Ibid., K. i. no. 338, 278.

Ibid., K. i. no. 338, 276-278.

Idid., K. i. no. 371, 209.

Ibid., K. i. no. 371, 210.

Ibid., K. i. no. 371, 210.

Ibid., Napló [Journals] vol. VII, 277. Speech by L. Mocsáry.

Ibid., Napló [Journals] vol. VII, 277.

Ibid., Napló [Journals] vol. VII, passim. Speech by Imre Veszter.

Ibid., Napló [Journals] vol. VII, 290.

Ibid., Napló [Journals] vol. VII, 290.

Ibid., Napló [Journals] vol. VII, 292. Speech by Pál Hoffman.

Ibid., Napló [Journals] vol. VII, 292.

Ibid., Napló [Journals] vol. VII, 302-303.

"...in ten years under this Act who is to prevent every single person from faraway eastern lands from being a Hungarian citizen, representative and minister ...? It is required by the very existence of the nation that we have to offer the safeguard to the country that the majority of the legislature will always be constituted by natural born Hungarians, and no one may be involved only those who with respect to their merits have been made deserving by the legislature ..." Ibid., Napló [Journals] vol. VII, 307, 309.

44 From among the 442 representatives being validly present, 105 voted yeas, 74 voted nays, while the others were absent. For that matter, this "under representation" was typical of the whole period, and the majority of representatives expressed their lack of concern for the issue by their absence.

45 When considering the speeches held throughout the debate, Dániel Irányi's contribution can be regarded as an outstanding one: “... I view it as impossible that this provision of Act 1868 shall be amended by the common Parliament. I view this right as impossible: impossible with respect to national dignity, and impossible for prudence. Law cannot allow a bilateral agreement to be withdrawn unilaterally. Law requires that a bilateral agreement be modified by common assent. Even national dignity, the chivalry of the nation cannot endure that what has been promised solemnly, may be recalled ... Ultimately, prudence cautions us, gentlemen, against offending those without a cause whose friendship may be highly precious to us, and whose hostile vein may hurt us." Ibid., Napló [Journal], vol. VII, 324.

46 Márton Hegyessi's speech seems to be typical: "More than 40 years ago, István Széchenyi said that we were so few in number that even the parricide had to be given pardon - just not to let Hungarian people abate, yet we had the tendency to find artificial causes to diminish ourselves as we could." Ibid., Napló [Journals], vol. VII, 365.

$47 \quad$ Ibid., Napló [Journals], vol. VII, 370.

48 Ibid., Napló [Journals], vol. VII, 376.

49 Ibid., Napló [Journals], vol. VII, 377.

Ibid., K. i. no. 383, 242.

Ibid., K. i. no. 383, 243.

Ibid., K. i. no. 383, 243.

Ibid., K. i. no. 403, passim.

54 The related request was made by the Prime Minister in his summons no. 3392, dated December 6, 1879. OLI: K $26-1879$ - II - 3498 (1879 - II - 203).

55 To read the full text see: OLI: K26 - 1879 - II - 3498 (1879- II - 203). 
56 Andor Csizmadia, "A magyar állampolgársági jog fejlődése" [The Development of Hungarian Citizenship Law] Állam és Közigazgatás (1969): 1083-1084; Károly Kisteleki, ibid., 43-50; Károly Besnyő, ed., A magyar állampolgárság (Megszerzése és elvesztése a gyakorlatban) [Hungarian Citizenship (Its Acquisition and Loss in Practice)] (Budapest, 1982), 29-31, Károly P. Szathmáry, ed., ibid., vol. VII, (Budapest, 1879), 213, 246, 268-286, 290-337, 339-402; Károly P. Szathmáry, ed., Az 1878. évi október 17-ére hirdetett országgyülés képviselöházának naplója [Journals of the House of Representatives of the Parliament summoned for 17 October 1878], vol. VIII (Budapest, 1879), 111, 248; Ibid., 1880, vol. IX, 226. As concerning the debate on the citizenship law, further guidance can be found in the proceedings of the House of Representatives: Az 1878. évi október hó 17-re hirdetett országgyülés képviselöházának jegyzökönyve [Proceedings of the House of Representatives of the Parliament summoned for 17 October 1878] volume II (Budapest, 1879), 17, 21, 24-29, 35, 40-62, 77-78, 93, 101-102, 153; Hugó Maszák, ed., Az 1879. évi október 17-re hirdetett országgyülés förendi házának naplója [Journals of the Upper House of the Parliament summoned for 17 October 1878] vol. I (Budapest, 1880), 303, 310-312, 317, 370. The text and justification of the act passed can be found in the National Archives under no. 2387/1879. K $26-1879-$ II -3498 (1879 - II - 203).

57 Hugó Maszák, ed., Az 1879. évi október 17-re hirdetett országgyülés förendi házának naplója [Journals of the Upper House of the Parliament summoned for 17 October 1878] vol. I (Budapest, 1880), 303, 310-312, 317, 370.

58 Ferenc Ferenczy, Magyar állampolgársági jog [Hungarian citizenship law] (Gyoma, 1930), 57; Emanuel Milner: Studien zum Österreichischen Staatsrechte I. Die Österreichische Staatsbürgerschaft und der Gesetzartikel L: 1879 über den Erwerb und Verlust der Ungarischen Staatsbürgerschaft. (Tübingen, 1880), 47-48; According to the Civil Code of 1811, Austrian citizenship could be acquired by way of marriage, legitimization, descent, naturalization, and entering civil service. The last case was a debated one, since the above mentioned law also declared that only Austrian citizens could undertake public office. Olivér Eöttevényi Nagy, Osztrák közjog [Austrian public law] (Budapest. 1913), 46-47; Andor Csizmadia, ibid., 1084-1085; Géjza Ferdinándy, Magyarország közjoga (Alkotmányjog) [Public law of Hungary (Constitutional law)] (Budapest, 1902), 238; Gusztáv Ladik, Közigazgatásunk fejlödése 1867. óta [The development of Hungarian public administration since 1867] (Budapest, 1933), 11. Imre Zlinszky, A magyar magánjog mai érvényben különös tekintettel a gyakorlat igényére [Hungarian private law in effect today, with special attention to the demands of practice] (Budapest, 1894), 50-51; Jenő Pongrácz, Magyar állampolgárság és községi illetőség. Törvények, rendeletek, elvi határozatok, dijak és illetékek, magyarázat, iratminták [Hungarian citizenship and township residence. Laws, decrees, principle decisions, fees and dues, explanation, sample documents] (Budapest, 1938), passim.

59 We must also note, however, that the law nevertheless also contained some methods of acquisition of citizenship, which were not mentioned in Section 3 of Act 50 of 1879. These were the following: the "right of land" (jus soli) and favored re-naturalization. Ferenc Ferenczy,: ibid., 57 , Act 50 of 1879, Section 19, 38-44.

60 Sándor Berényi, Nándor Tarján, A magyar állampolgárság megszerzése és elvesztése (honosság, letelepülés, kivándorlás, útlevélügy). Az 1879. évi L. törvény-czikk és az ezzel kapcsolatos törvények s rendeletek gyüjteménye és magyarázata [The acquisition and loss of Hungarian citizenship (national status, settling, emigration, passport regulations). A collection and explanation of Act 50 of 1879, as well as related laws and regulations] (Budapest, 1905), 14; Ferenczy, ibid., 57.

61 Ferenczy, ibid., 58.

62 Zlinszky, ibid., 50-51. 
63 Ibid., 51

64 In case of birth it is the transfer of an old right and not the obtaining of a new one, which proves that the child is not an acquirer of rights, only the inheritor of an already existing right. Ferenczy, ibid., 58.

65 The practical implementation of the law, however, raised a number of issues with regard to which several supplementary regulations had to be issued by the competent ministries. Decree of the Minister of the Interior no. 24.553/1888. in.: Ferenczy, ibid., 153.

66 Ferdinándy, ibid., 238-239; Arthur Balogh, Politikai Jegyzetek [Political notes] (Budapest, 1905), 91; Ferenczy, ibid., 31.

67 Imre Korbuly, Magyarország közjoga illetőleg a magyar államjog rendszere [Hungarian public law and the system of Hungarian state law] (Budapest, 1884), 138; Kisteleki, ibid., 50; Ferenczy, ibid., 31-32.

68 Ministry of the Interior official communication no. 33.325/1888; in: Ferenczy, ibid., 156.

69 Ferenczy, ibid., 32.

70 Ibid., 32; Ministry of the Interior Decree no. 20.723/1896 in: Ibid., 175.

71 Korbuly, ibid., 140; Ferenczy, ibid., 34.

72 Korbuly, ibid., 140; Nagy, ibid., 109.

73 Ferenczy, ibid., 34-35; Ministry of the Interior Decree no. 20.723/1869 in: Ibid., 175.

74 Ferdinándy, ibid., 239. The original Hungarian expression "férjhez megy" can only be applied to women. The author maintains that, apart from being more genuinely Hungarian, this expression better expresses the fact that only a woman was able to acquire Hungarian citizenship this way.

$75 \quad$ Ibid., 239

76 Ferenczy, ibid., 86; József Tar, Állampolgárság [Citizenship] (Debrecen, 1941), 25.

77 Berényi, Tarján, ibid., 109-111.

78 Géjza Ferdinándy on the other hand, used the expression "honfiúsítás" together with "honosítás." Ferdinándy, ibid., 238-239.

79 Ferenczy, ibid., 35. Date of coming into force: January 5, 1880.

80 The provision was in effect in Hungary whereby if an Austrian citizen immigrated to Hungary in the 1840 s or 1850 s, then he could obtain Hungarian citizenship by way of simple naturalization. In case of returning to his original country, however, this acquired right was lost. The royal decree no. 10.661 of 1814 was applied whereby citizenship could be acquired implicitly by uninterrupted and proved residence in the country for ten years. Ministry of the Interior registry no. 553/1887 in.: Ferenczy, ibid., 153-154. The same is set forth in Ministry of the Interior Decree no. 2194/1886. in: Ibid., 155.

81 Arthur Balogh differentiated between them on the basis of the legal consequences effected by naturalization, and accordingly differentiated between naturalization of smaller and larger legal effect, similarly to Belgians. Balogh, ibid., 91-92.

82 Ministry of the Interior decree no. 115.702/1904 in: Ferenczy, ibid., 167. The connection between naturalization and township residence is further regulated by Ministry of the Interior decree no. 8497/1905 in: Ferenczy, ibid., 167-168.

83 Korbuly, ibid., 139; Ministry of the Interior executive decree no. 584/1880 in: Ferenczy, ibid., 163. According to the Austrian Civil Code of 1811, the following conditions had to be met for naturalization: legal capacity, no criminal record, proof of income, admittance to a township either concluded or in progress. Naturalization belonged to the competence of provincial authorities with the Minister of the Interior intervening in cases of disputed issues only. A certificate of the naturalization was issued, and an oath had to be taken. Minors were either exempted from under the oath, or it was postponed until they would come of age. Eöttevényi, ibid., 47. 
84 Such regulation also appears in the citizenship law of the United States of America, which causes problems more than once in naturalization cases. In.: Katalin Gönczi, A magyarok az amerikai Legfelsőbb Bíróság elött [Hungarians before the Supreme Court] (Budapest, 2000), 46-51; Ferenczy, ibid., 59-60.

85 Official communication of the Ministry of Justice no. 26.538/1904 in: Ferenczy, ibid., $164-165$.

86 Ministry of the Interior Resolution no. 3257/1886 in: Ferenczy, ibid., 159-160. If their conjugal life was subsequently restored, then the husband's citizenship was also extended to his wife. Official communication of the Ministry of Justice no. 52.280/1900 in: Ferenczy, ibid., $160-162$.

87 József Kun, Nép, nemzet, nemzetiség [People, nation, nationality] (Budapest, 1908), 174-175; Ferenczy, ibid., 61.

88 Ministry of Finance Decree no. 44.130/1881 in: Ferenczy, ibid., 168-169.

89 Balogh, ibid., 91.

90 Ferenczy, ibid., 62.

91 Ministry of the Interior Decree no. 584/1880 in: Ferenczy, ibid., 172; Ministry of the Interior Decree no. 29.212/1895 in: Ibid., 174.

92 Ferenczy, ibid., 63.

93 Ferdinándy, ibid., 242.

94 Ernő Nagy, ibid., 111; Edit Madari and Maria Parragi, The New Act on Hungarian Nationality. Acta Juridica Hungarica (1993), 68; József Hargitai, A magyar állampolgársági jog de lege lata (gondolatok néhány alapelvről) [Hungarian citizenship law de lege lata (thoughts on some basic principles)]. Magyar Jog (1993) 721.

95 65.268/1888. Ministry of the Interior official communication in: Ferenczy, ibid., 170.

96 A certificate of Hungarian citizenship could also only be issued by the Hungarian Royal Minister of the Interior. Ministry of the Interior Decree no. 24.565/1887 in: Ferenczy, ibid., 152. This was also underlined by the Ministry of the Interior's general decree no 45.516 of 1878 stating that county, municipal and township authorities did not have the powers to issue such certificates in: Ibid., 152.

97 Ferenczy, ibid., 64.

98 Act 50 of 1879, Section 14. Ministry of the Interior Decree no. 584/1880 regulates the records to be made at the taking of the oath, in.: Ferenczy, ibid., 172-173.

99 Korbuly, ibid., 140; Ferenczy, ibid., 65, 174.

100 Ferdinándy, ibid., 239-242; Ernő Nagy, ibid., 111-112.

101 Ernő Nagy, ibid., 110. A similar agreement was also in place between Hungary and Serbia (Act 30 of 1882).

102 Ferenc Ferenczy argues that the word "re-naturalization" is not appropriate, since the person involved is not "regaining some old, lost right," but is acquiring a new right. "Citizenship by way of so-called re-naturalization is not restitutio in integrum, but a new citizen's right." He saw this reasoning justified by the taking of the oath and other, similar procedural rules. Ferenczy, ibid., 66; Pongrácz, ibid., 28-29.

103 Ferenczy, ibid., 65.

104 Ibid., 66.

105 A child otherwise of legal age could not obtain citizenship by the right of his or her father. Ministry of the Interior Decree no. 1556/1887 in: Ferenczy, ibid., 157; Pongrácz, ibid., 30-31.

106 Such certificates had no temporal restrictions; however, if a person lost his or her citizenship due to ten years' of absence, then the certificate itself also became ineffective. It was considered as an authentic proof of citizenship until proved otherwise. Ministry of the Interior official communication no. 44.451/1900 in: Ferenczy, ibid., 152. 
107 Pongrácz, ibid., 31-32; Ferenczy, ibid., 67.

108 Ernő Nagy, ibid., 116.

109 Ferenczy, ibid., 68.

110 The law made it possible for the Csángó [Hungarian-speaking native of Moldavia] Hungarians of Bukovina to re-settle in large numbers, "and was brought to existence by the recognition that these otherwise lost Hungarians should be saved for the Hungarian nation, and should be given every concession to facilitate their return. It is not impossible that this law will make good services in the future as well." Ferenczy, ibid., 68-69; Ernő Nagy, ibid., 116; Pongrácz, ibid., 32.

111 Korbuly, ibid., 138; Kisteleki, ibid., 50; Ministry of the Interior Decree no. 23.319/1903. in: Ferenczy, ibid., 158; Ernő Nagy, ibid., 109.

112 Ministry of the Interior official communication no. 52.550/1903, Ministry of the Interior Decree no. 27.899/1904. in.: Ferenczy, ibid., 158-159.

113 Ferdinándy, ibid., 239. 
